\title{
PETER THE GREAT IN N.M. KARAMZIN'S REFLECTIONS
}

\author{
Ruslan R. Dzhabbarov \\ Saratov Socio-Economic Institute (Branch) of Plekhanov Russian University of Economics, Saratov, \\ Russian Federation
}

\begin{abstract}
Introduction. The conservative trend is fashionable and highly sought in the political discourse of modern Russia. This indicates the relevance of studying the history of conservative thought. The novelty of the article is the attraction and analysis of new sources, which made it possible to concretize the attitude of N.M. Karamzin to Peter I. The aim of the study is to identify and establish the views of Karamzin on the role of Peter the Great in the history of Russia. The objectives are to identify the stages and directions of the evolution of the views of N.M. Karamzin on the reformer and his activities, determining the causes of its changes. Methods. The article uses the problem-chronological method within the framework of intellectual history. Analysis. Based on the analysis of the historian's work, it is asserted that through the end of the $18^{\text {th }}$ century N.M. Karamzin extolled Peter the Great and justified his cruel reformation methods. Starting from the reign of reform-minded Alexander I of Russia and being influenced by revolutionary events in France, the Russian historian began to criticize Peter the Great. In his Memoir on Ancient and Modern Russia the historian criticized Peter's violation of national traditions and his barbaric methods of the country's Europeanization. Later, in the closing stages of the reign of Alexander I, the historian having considered Russia's victory over France, stepped back to his positive evaluation of Peter the Great as the ruler of the country, who laid the groundwork for Russia's power and prestige. Results. Thus, the article analyzes the evolution of the views of the major ideologist of Russian conservatism N. M. Karamzin on the role of Peter the Great in Russian history. Research gaps are closed, requiring filling by engaging sources for analysis not previously involved in scientific circulation.
\end{abstract}

Key words: N.M. Karamzin, Peter the Great, reforms, Europeanization, church, conservatism.

Citation. Dzhabbarov R.R. Peter the Great in N.M. Karamzin's Reflections. Vestnik Volgogradskogo gosudarstvennogo universiteta. Seriya 4, Istoriya. Regionovedenie. Mezhdunarodnye otnosheniya [Science Journal of Volgograd State University. History. Area Studies. International Relations], 2019, vol. 24, no. 1, pp. 98108. (in Russian). DOI: https://doi.org/10.15688/jvolsu4.2019.1.8

УДК 94(47)

ББК 63.3(2)5
Дата поступления статьи: 23.01.2018 Дата принятия статьи: 07.05.2018

\section{ПЕТР ВЕЛИКИЙ В ОЦЕНКЕ Н.М. КАРАМЗИНА}

\author{
Руслан Рашидович Джаббаров \\ Саратовский социально-экономический институт (филиал) Российского экономического университета \\ им. Г.В. Плеханова, г. Саратов, Российская Федерация
}

\footnotetext{
Ан Анотация. Статья посвящена эволюции взглядов крупного идеолога русской консервативной «партии» 尺े Н.М. Карамзина на роль Петра Великого в российской истории. На основе анализа творчества историка утверждается, что до конца XVIII в. Н.M. Карамзин превозносил Петра І и оправдывал его жестокие методы преобразований. В «Письмах русского путешественника» Н.М. Карамзин восхищался петровской европеизацией России, считая ее прогрессивной и отвечающей национальным интересам. Выяснено, что историк даже планировал написать «Историческое похвальное слово Петру I». С началом реформаторского правления Александра I и под влиянием революционных событий во Франции последовала критика Петра Великого со стороны российского историографа. Он обвинял Петра І в унижении национального самолюбия, хотя при этом признавал успешность его военных реформ. В «Записке о древней и новой России в ее политическом
} 
и гражданском отношениях» историк критиковал нарушение Петром I национальных традиций и его варварские методы европеизации страны, хотя в целом Н.М. Карамзин признавал императора как основателя великой европейской державы. В последние годы царствования Александра I историк, осмысливая победу России над Францией, вновь позитивно оценивает годы самодержавия Петра I как правителя страны, заложившего основы ее могущества.

Ключевые слова: Н.М. Карамзин, Петр Великий, реформы, европеизация, церковь, консерватизм.

Цитирование. Джаббаров Р. Р. Петр Великий в оценке Н.М. Карамзина // Вестник Волгоградского государственного университета. Серия 4, История. Регионоведение. Международные отношения. - 2019. - Т. 24, № 1. - C. 98-108. - DOI: https://doi.org/10.15688/jvolsu4.2019.1.8

Введение. В политическом дискурсе современной России популярным и востребованным является консервативный тренд. К сожалению, не все объявляющие себя сторонниками идеологии и политики консерватизма представляют, что стоит за этим термином. Ведь подлинный консерватизм - это не просто отрицание либеральных или социалистических идей, а сложная масштабная система взаимосвязанных ценностей. В отечественной истории был период, когда идеология консерватизма являлась господствующей не только в правящих верхах, но и в обществе. Таким периодом, несомненно, был XIX в., когда идеология консерватизма реализовывалась системно и сознательно. Время царствования Николая I и Александра III, на наш взгляд, есть прямое и яркое подтверждение вышесказанного.

Своими корнями консервативная идеология уходит в XVIII в., когда зарождаются идейные основания русского консерватизма в дворянской и церковной среде. Представляется, что возникновение консервативных воззрений в общественной мысли России во второй половине XVIII в. было реакцией на преобразования Петра I, часть которых виделась их носителями разрушительными для страны. В числе тех, кто формировал политический консерватизм, был, как известно, выдающийся российский историк и литератор Н.М. Карамзин (1766-1826), который на протяжении всей своей творческой жизни пытался осмыслить феномен первого российского императора.

Н.М. Карамзин как представитель консервативной общественной мысли России и эволюция его взглядов на личность и деятельность Петра I были и остаются объектом научного интереса историков разных поколений. В дореволюционное время к этой проблеме обращался профессор Е.Ф. Шмурло. Ученый утверждал, что вплоть до конца XVIII в. Н.М. Карам- зин апологизировал Петра I, но в «Записке о древней и новой России в ее политическом и гражданском отношениях» (далее - «Записка») подверг его беспощадной критике. А в 1818 г. он вернулся, по мнению Е.Ф. Шмурло, к первоначальным воззрениям на Петра І. Свои оценки профессор Е.Ф. Шмурло сделал на основе анализа ряда сочинений Н.М. Карамзина, среди которых, к сожалению, неупомянута «История государства Российского», «Рассуждение о любви к отечеству и народной гордости» $[18$, № 7 , с. 79-80, 98-99; № 8, с. 334].

Воззрения Н.М. Карамзина на прошлое и настоящее России активно исследовались советскими учеными $[5 ; 7 ; 12]$. К примеру, В.И. Корецкий в «Советской исторической энциклопедии» представлял Н.М. Карамзина как выразителя интересов аристократии, жестким критиком преобразований Петра I [15, с. 95]. Строго говоря, проследить мировоззренческую эволюцию взглядов советских историков достаточно сложно.

В постсоветский период обращают на себя внимание работы В.А. Китаева [7], Е.А. Соловьева [16, с. 39-42, 44-51], А.Ю. Минакова [10, с. 384-387], в которых определенное место отведено исследованию личности и деятельности Петра I в творчестве Н.М. Карамзина. Необходимо обратить внимание на концепцию В.А. Китаева, согласно которой Н.М. Карамзин проделал эволюцию от апологии Петра І в молодости до консервативной критики его реформ в более зрелом возрасте [6, c. 7, 15-16]. Е.А. Соловьев углубил и конкретизировал концепцию Е.Ф. Шмурло, отметив, что карамзинская критика Петра I началась уже в конце XVIII в. [16, с. 44]. А.Ю. Минаков отмечал раннюю апологию Петра I H.M. Карамзиным, делая акцент на его позднюю критику самодержца в «Записке». Дальнейшая эволюция взглядов Н.М. Карамзина не стала пред- 
метом исследования ученого [11, с. 387]. Саратовский историк С.А. Мезин полагает, что «зрелый» Н.М. Карамзин критиковал Петра I под влиянием текстов Д. Дидро, практически дословно их повторяя в своей «Записке» $[9$, c. 19-20].

В целом следует признать, что отечественные авторы внесли значительный вклад в интерпретацию причины эволюции взглядов H.M. Карамзина на Петра I, привлекая для этого значительный пласт его творческого наследия.

Из зарубежных публикаций проблеме отражения образа Петра I в общественной мысли России посвящена книга американского историка русского происхождения H.В. Рязановского «The Image of Peter the Great in Russian History and Thought» [19, p. 67-75]. Отсутствие русского перевода делает ее менее доступной для исследователей. Автор использует не весь объем источников, допуская ряд хронологических неточностей. Характеризуя «Записку», ученый отмечает, что Н.М. Карамзин не только критиковал Петра I, но и признавал ряд его положительных качеств, не упоминая при этом «пороки личные» [19, p. 73].

Таким образом, несмотря на ряд имеющихся работ, трактующих взгляды Н.М. Карамзина на личность Петра I и методы его реформаторской деятельности, остаются исследовательские лакуны, которые требуют заполнения посредством привлечения для анализа ранее не привлекаемых в научный оборот источников.

Новизна статьи заключается в привлечении и анализе новых источников, позволивших конкретизировать и уточнить эволюцию взглядов Н.М. Карамзина на жизнь и деятельность Петра I.

Целью исследования стало выявление и установление взглядов Н.М. Карамзина на роль Петра Великого в истории России. Задачами являются выделение этапов и направленности эволюции взглядов Н.М. Карамзина на реформатора и его деятельность, определение причин изменения его мировоззрения.

Методы. Статья написана в методологических рамках интеллектуальной истории. В данной концептуальной модели используется преимущественно проблемно-хронологи- ческий метод, исторические факты исследуются на основе принципов историзма и объективности.

Анализ. Тема Петра I и его реформ, круто изменивших жизнь в России, впервые широко поднимается Н.М. Карамзиным в «Письмах русского путешественника» (далее «Письма»). Это произведение частично публикуется в «Московском журнале» в 17911792 гг., а полностью вышло отдельным изданием в двух вариантах в 1797-1801 годах. Ярче всего отношение автора к царю-реформатору проявляется, когда он устами русского путешественника во Франции сравнивает памятники разным правителям: памятник Петру І в Петербурге и Людовику XIV в Лионе. Хотя монументы двум правителям одинаковы по величине, по мнению Н.М. Карамзина, «сии два героя были весьма неравны в великости духа и дел своих» [2, т. 1, с. 243].

Раскрывая свою мысль, Н.М. Карамзин отмечал, что «подданные прославили Людовика, Петр I прославил своих подданных». Если Людовик XIV частично содействовал достижениям «просвещения», то Петр Великий, «как лучезарный бог света», обнаружился на небосводе людского рода и озарил невозмутимый мрак перед собой. По Н.М. Карамзину, в правление Людовика XIV тысячи прилежных французов были навсегда вынуждены покинуть родину, Петр I же пригласил в страну дельных и практичных иностранцев. Н.М. Карамзин признавал «короля-солнце» влиятельным «царем», Петра Великого же ценил «как великого мужа, как героя, как благодетеля человечества», считая его «своим собственным благодетелем».

Итак, ранний Карамзин разделял не только всеобщее преклонение перед Петром I, но и испытывал глубоко интимное чувство благодарности монарху, соучастия его делу, направлявшее умы многих образованных россиян на протяжении первой половины ХІХ столетия.

Саму идею «поставить статую Петра Великого на диком камне» Н.М. Карамзин считал «прекрасной» и «несравненной», «ибо сей камень служит разительным образом того состояния России, в котором была она до времен своего преобразователя» $[2$, т. 1, с. $343-$ 344]. Подобное толкование памятника перво- 
му императору в полной мере отвечало не только авторскому замыслу, но и доминировавшему в среде русского просвещенного общества XVIII столетия представлению о Петре I как правителе, цивилизовавшем варварскую Россию.

Н.М. Карамзин возвращался к теме Петровских реформ, повествуя о своей встрече с французским историком П.-Ш. Левеком. Сочиненная последним «Российская история» была, по словам Н.М. Карамзина, «лучше всех других», хотя ее автор «унижал» Петра I, обвиняя его в подражании чужеземцам. Но для Н.М. Карамзина П.-Ш. Левек - «посредственный французский писатель», который только и «может унизить нашего славного монарха». Мнения о Петре I, подобные П.-Ш. Левеку, Н.М. Карамзин слышал «даже от русских», но «никогда не мог» воспринимать такое суждение «без досады».

На переломе двух веков проводимая Петром I европеизация России казалась Н.М. Карамзину прогрессивной и полностью отвечавшей задачам, стоявшим перед страной. Н.М. Карамзин полагал, что все народы идут последовательно по одному и тому же пути Просвещения. Русским людям надлежит учиться у более «умных» европейцев и перенимать их опыт. Царь решительно боролся с национальными традициями, потому что они, с одной стороны, были устаревшими и негодными для своего времени, а с другой стороны, мешали введению «важнейших и полезнейших» иностранных порядков. Следовало, по Н.M. Карамзину, раз и навсегда покончить с русским консерватизмом, чтобы сделать народ уступчивым, восприимчивым и обучаемым. Главное - общечеловеческие ценности, а не национальная самоидентификация [2, т. 1, c. 415-418].

Жестокие методы царя-реформатора тогда казались Н.М. Карамзину полностью оправданными. Стремление же П.-Ш. Левека отыскать в истории России правителя, противоположного Петру I, повергало автора «Писем» в удивление. Французский историк полагал, что русские сами развились бы до современного ему состояния, даже если бы Петр I не правил. Н.М. Карамзин возражал французу, считая, что царь изрядно поработал, чтобы побороть русскую стойкость «в неве- жестве». Следовательно, русские не хотят «просвещаться» и не имеют задатков к этому. По Н.М. Карамзину, связь России с Европой была опосредованной и обременительной. Ее «просвещение» только слегка повлияло на Россию, поэтому за 200 лет по «естественному, непринужденному ходу» вряд ли было бы достигнуто то, что Петр Великий сотворил за 20 лет. Согласно Н.М. Карамзину, Россия не могла бы стать известной без Петра I, так же как «Спарта без Ликурга».

Следовательно, Н.М. Карамзин в «Письмах русского путешественника», рисуя блестящий образ Петра I, подводил итог догорающему столетию с характерным большинству его образованных соотечественников восхвалением царя-реформатора. Однако это было восхваление без подобострастия, осуществленное, ко всему прочему, обновленным художественным языком, который впоследствии даст начало Золотому веку русской культуры [16, c. 42].

Тема Петра I продолжала волновать Н.М. Карамзина и в последующее время. В записной книжке 11 июня 1798 г. он раскрывает план написания похвального слова Петpy I [11, с. 127]. В письме к И.И. Дмитриеву 20 сентября того же года Н.М. Карамзин пишет, что ему «хотелось бы между прочим написать два похвальных слова Петру Великому и Ломоносову» [13, с. 102]. Но эти планы так и не были осуществлены.

Время царствования Павла I, стремительное развитие политических событий в Европе, и особенно в пореволюционной Франции, оказали большое влияние на отношение H.M. Карамзина к царю-реформатору. Уже к началу нового столетия у него появляется некоторый скепсис в оценке реформ Петра I [2, т. 2, с. 146-147], который еще более усилился с вступлением на престол Александра I.

Было очевидно, что молодой император не был расположен к преклонению перед Петром Великим. Возможно, определенное влияние оказали либеральные воззрения Александра I, особенно примечательные в первые полтора десятилетия правления, явно не позволявшие возводить личность Петра Великого в культ. Нельзя не признавать и специфику личных предпочтений Александра I, его склонность к мистицизму. 
Ответом на либеральные реформы, проводимые в России в начале XIX в., стало усиление в обществе консервативных начал. В это время воззрения Н.М. Карамзина на историю России и роль в ней Петра Великого существенно меняются [7, с. 218-219].

Будучи человеком с литературным именем и талантом историка, он был замечен придворной элитой в лице сестры Александра I Екатерины Павловны. Это позволило Н.М. Карамзину в «Историческом похвальном слове Екатерине II» (далее - «Слово»), переданном императору по случаю вступления на престол, изложить молодому самодержцу свою политическую программу [14, с. 40].

Судя по тому, как будут дальше складываться отношения Н.М. Карамзина и Александра I, следует констатировать, что проявившиеся в «Слове» политические воззрения автора были приняты самодержцем. Исследователи творчества Н.М. Карамзина давно отмечали, что его политические взгляды на историческое прошлое России и ее будущее к началу XIX в. претерпели существенное изменение по сравнению с тем, что они представляли до начала Французской революции [10, c. 384].

События во Франции, сопровождающиеся казнью короля Людовика XVI, большой кровью и последующими событиями, разрушающими сложившийся государственный уклад страны, значительно меняют взгляды H.М. Карамзина. Идеи французского Просвещения становятся для историка не столь притягательными и обязательными для развития России.

А.С. Пушкин определил первые шаги во внешней и внутренней политике молодого царя как «дней Александровых прекрасное начало». Действительно, царское правительство в лице «Негласного комитета» приступило к либеральным реформам, возвращаясь к политике «просвещенного абсолютизма». Вдохновителем правительственного либерализма выступил сам Александр I. Разработчиком плана государственных преобразований становится М.М. Сперанский.

Нововведения в управлении государством вызвали антиалександровские настроения у части придворного окружения. Противостоять этим либеральным начинаниям была призвана консервативная «партия», олицетворением которой был салон Екатерины Павловны, где за Н.М. Карамзиным признавался авторитет мыслителя, крупного идеолога, способного составить конкуренцию М.М. Сперанскому в выработке стратегии и тактики государственной политики [14, с. 41$]$.

В условиях начавшихся реформ, затрагивающих основы государственного управления и социальных отношений, просвещенные умы России, желая учесть исторический опыт, вновь обращались к теме Петра I. Будучи сторонником насильственной европеизации, Петр I вызывал противоречивые оценки у консерваторов первой четверти XIX в., таких как Н.М. Карамзин, А.С. Шишков, С.Н. Глинка.

В 1802 г. Н.М. Карамзин опубликовал рассуждение «О любви к отечеству и народной гордости», в котором призывал русских людей покончить с рабским копированием всего европейского и предлагал возвратиться к народному самосознанию и национальному своеобразию. Н.М. Карамзин полагал, что Петр I, делая из русских европейцев и демонстрируя им преимущества «просвещения», на недолгое время «унизил» их национальное самолюбие. Россия обратила взор на Европу и возомнила, что этим заимствует результаты ее длительных трудов. Но в то же время Н.М. Карамзин отмечает, что Петр I научил русскую армию владеть новым оружием, благодаря которому она смогла одержать победу над шведами. Русские генералы сначала были учениками, а потом и примерами для учителей. Историк этим самым признает успешность военных реформ. По мнению Н.М. Карамзина, народ, начав с подражания, должен со временем стать самим собою, чтобы заслужить право на моральное существование. В рассуждении автор дает свое понимание патриотизма: патриот должен прививать Родине полезное и необходимое, но отвергать заимствования в мелочах. «Мы никогда не будем умны чужим умом и славны чужой славою. <..> Хорошо и должно учиться, - пишет Н.М. Карамзин, - но горе человеку и народу, который будет всегдашним учеником» $[4$, c. 66,69$]$.

Н.М. Карамзин призывал сражаться с губительным воздействием иностранных порядков, разделяя мнение видного консервато- 
ра адмирала А.С. Шишкова о необходимости развязать войну «тем развратным нравам, которым новейшие философы обучили род человеческий и которых пагубные плоды, после толикого пролития крови, поныне еще во Франции гнездятся» [17, с. 423].

Согласно Н.М. Карамзину, поэзию русские люди сочиняли задолго до Петра I. Еще до Петра I у русских были романсы и песни, где сердечно и бесхитростно повествуется о любви и дружбе. Аргументируя свою мысль, H.М. Карамзин своеобразно пересказывает народные песни. Историк подчеркивал, что Петр І открыл для россиян цивилизацию европейских народов и достижения западных наук, подтолкнув свой народ к обучению. Это привело к тому, что русские были оскорблены пониманием своей неразвитости и поэтому стремились копировать все у европейцев: «в образе жизни и в платье, в обычаях и искусствах». Он переиначил свой язык по образцу «немецкого и французского». Кроме того, «поэзия и словесность» русских стали эхом европейских аналогов.

Наиболее ярко о повороте мировоззрения Н.М. Карамзина сигнализировала «Записка о древней и новой России в ее политическом и гражданском отношениях» [1, с. 185-254], написанная им в 1811 г. лично для императоpa, чтобы ослабить его реформаторский пыл. В этой связи приобретала важнейшее значение оценка роли и места Петровских реформ.

$\mathrm{B}$ «Записке» красной нитью проходила нашедшая в скором будущем широкое признание мысль о взаимосвязанности истории России XVII-XVIII веков. Правление первых Романовых противопоставлялось царствованию Петра I, радикально изменившего «все». До Петра I изменения шли плавно, без резких толчков, новые веяния соединялись «со старым». Таким образом, Н.М. Карамзин постепенно пытался подвести читателя к мысли, что Россия и без Петра I «могла бы прославиться».

Следует отметить, что в «Записке» давалась подробная характеристика деятельности предшественников Петра I на троне из династии Романовых. На этом фоне только единожды была упомянута сестра Петра I правительница Софья. В то время как еще в «Пантеоне российских авторов» (периодическом издании, выходившем в 1801-1802 гг.) она названа Н.М. Карамзиным одной из самых великих женщин, «произведенных Россиею». Софья была поставлена Н.М. Карамзиным на одну доску с Петром Великим, однако в том же произведении он отмечает ее властолюбие, деспотизм и эгоизм. Здесь же Н.М. Карамзин отметил литературный дар и актерский талант Софьи. Характеризуя ее трагедии и драмы, он сравнивает ее с лучшими сочинительницами в истории. Но Н.М. Карамзин сетует на отсутствие у правительницы «просвещенного вкуса». В «Записке» же эта противоречивая характеристика превращается в отрицательную: речь идет только о «властолюбии» правительницы. Возможно только предполагать, с чем связана подобная эволюция воззрений Н.М. Карамзина. С одной стороны, она была лишь правительницей, а не царицей, что имело большое значение для консерватора, с другой - в стране оставалась угроза дворцового переворота с целью возведения на престол сестры Александра I Екатерины Павловны. Скорее всего, Н.М. Карамзин пытался избежать невольных сравнений с современностью.

Подводя итог правлению Петра I, Н.М. Карамзин двояко оценивал последствия его политической деятельности: «не только новое величие России, но и совершенное присвоение обычаев европейских» [1, с. 194]. Он признавал заслуги Петра I как основателя великой европейской державы, подчеркивая его «важнейшее для самодержцев дарование: употреблять людей по их способностям» [1, с. 194-195]. Историк даже ставил в пример царствующему монарху петровский талант находить нужных людей, порицая склонность фаворитов Александра I к изменению государственных порядков [1, с. 236-237].

С другой стороны, Н.М. Карамзин обращал внимание на отрицательные итоги правления Петра I. Не останавливаясь специально на «пороках личных», автор «Записки» обрушивался с критикой на петровскую политику вестернизации. Государство, считал историк, может перенимать из-за рубежа полезный опыт, не копируя традиции: «Пусть сии обычаи естественно изменяются».

Считая эту политику вредной, Н.М. Карамзин находил в допетровской истории факты прямо противоположных, договорных отно- 
шений между монархом и народом. «Народ в первоначальном завете с венценосцами сказал им: “Блюдите нашу безопасность вне и внутри, наказывайте злодеев, жертвуйте частью для спасения целого”, - но не сказал: “противуборствуйте нашим невинным склонностям и вкусам в домашней жизни"» [1, с. 196]. В этой области правитель, само собой разумеется, не может приказывать, воздействуя на подданных исключительно своим примером.

Н.М. Карамзин, давая оценку преобразованиям Петра I, подчеркивал, что иностранные обычаи утверждаются очень долго и в этом серьезный изъян политики европеизации. К тому же Петр I реформировал в основном дворянство, не будучи в силах изменить весь народ. По мнению Н.М. Карамзина, страна оказалась расколотой в культурном отношении, что вело к негативным последствиям. Более того, прервалась вековая связь между «высшими» и «низшими» сословиями [1, c. 195-196].

К тому же Н.М. Карамзин обвинял Петpa I в принижении роли наследственного дворянства. Если раньше Н.М. Карамзин восхищался умением Петра I выбирать себе талантливых помощников, то теперь на высших постах в государстве историк мог видеть лишь как исключение самых выдающихся представителей непривилегированных сословий. По его мнению, родовитое, наследственное дворянство является опорой трона, поэтому назначаться на высшие должности могут только представители благородного сословия [1, с. 241-242].

Н.M. Карамзин считал виновным Петра I в том, что россияне, впитав общечеловеческие ценности, лишились «гражданских». Список потерь, понесенных русским народом, выглядел пугающе на фоне скорой войны с Наполеоном: «Имя русского имеет ли теперь для нас ту силу неисповедимую, какую оно имело прежде?» [1, с. 197]. Вина Петpa I в том, что русские, став космополитами, утратили, в определенных случаях, принадлежность к России [1, с. 197]. Н.М. Карамзин указывал на конфликт между национальными «склонностями, привычками, мыслями» и стремлением Петра I силой европеизировать русских. Это противостояние стало причиной петровской тирании, деспотических методов его правления: «пытки и казни» были методом осуществления Петровских реформ. Люди, по словам Н.М. Карамзина, погибали за честь русской одежды и бороды. Они критиковали царя, пытаясь сохранить традиции предков, ассоциировавшиеся у них с Родиной [1, c. 197].

Осуждая произвол и нетерпеливость Петра I, Н.M. Карамзин осуждал и его церковную реформу, в частности уничтожение патриаршества. Должность патриарха была отменена Петром I «как бесполезная для церкви и вредная для единовластия Государей». По Н.М. Карамзину, Петр Великий, помня о Никоне, стремился ослабить духовную власть [3, кн. 3, с. 73]. Историк обвиняет царя в тирании: «Петр царствовал и хотел только слуг» [3, кн. 1, с. 74]. Благодаря царюреформатору церковь снизошла до идеологического рупора государственной власти. Если, указывал Н.М. Карамзин, полная зависимость церкви от государства вызывает мысль о ее ненужности, то пример допетровской России и сражающейся Испании доказывает обратное. Н.М. Карамзин считал сильную церковь союзником государства в борьбе с Наполеоном.

Н.М. Карамзин критиковал Петра I за основание новой столицы на северной окраине страны, в тяжелых природных условиях [1, c. 197-199]. Здесь можно усмотреть явное влияние философских взглядов Д. Дидро, на что указывает почти текстуальное совпадение в оценке Петербурга в качестве новой столицы России. Скорее всего, в этом вопросе русский историк был последователем французского философа [9, с. 20]. Д. Дидро писал о «череде блестящих ошибок» Петра I, о невозможности «преодоления природы», о неестественности Петербурга, заложенного на окраине страны («сердце находится на кончике пальца»). Д. Дидро считал необходимым уменьшить значение Петербурга до заурядного порта или коммерческого склада. Французский писатель настаивал на переносе царского двора внутрь страны [8]. Как видим, Н.М. Карамзин был единодушен с Д. Дидро в решении этой проблемы. Однако прийти к отрицанию петровской политики европеизации и ее методов Н.М. Карамзин мог и без знакомства с сочинениями Д. Дидро. 
Тем не менее на этом резоне карамзинская характеристика Петра I не закончилась. Он умерил ее размышлениями о «великом муже», который «самыми ошибками доказывает свое величие: их трудно или невозможно изгладить - как хорошее, так и худое делает он навеки» [1, с. 199].

С течением времени отношение к Петpy I понемногу улучшалось. В 1815 г. в предисловии к «Истории государства Российского» Н.М. Карамзин утверждает, что лучи славы Ивана III падали на колыбель Петра I, то есть он признавал значимость правления первого императора. Период от Петра I до Александра I H.М. Карамзин относил к «новой» истории, для которой характерен переход от единовластия к реформированию «гражданских обычаев» [3, кн. 1, с. 10-11]. Далее, Петр I, по Н.М. Карамзину, величайший деятель в истории. В пользу Петра I говорит и упоминание Н.М. Карамзиным переноса царем мощей Александра Невского в новую столицу, которая была этим посвящена победителю крестоносцев [3, кн. 1 , с. 58]. Однако царь совершил ошибку, присвоив с честолюбивыми целями «чужеземное звание» императора. Н.М. Карамзин указал на сохранившийся немецкий подлинник русской договорной грамоты 1514 г., использованный Петром Великим как доказательство, что предки его именовались императорами и что Австрия официально признала их звание [3, кн. 2, с. 36]. Н.М. Карамзин ставит Петру I в упрек введение европейских порядков, изменение норм нравственности подданных. Петр I слишком много «пекся» о Просвещении и науках, чересчур покровительствовал иностранцам, унижая русский народ [3, кн. 2, с. 216-217].

Н.М. Карамзин более эффектно перефразировал апологию царю, выступив с речью на помпезном собрании Императорской Российской академии в декабре 1818 г.: «Петр Великий, могущею рукою своею преобразив отечество, сделал нас подобными другим европейцам. Жалобы бесполезны» $[2$, т. 2, с. 238].

Отношение к Петру I еще более улучшилось в 1821 году. Историк отмечает, что у Петра I было «великое дело» - захватить «море и гавани» для торговых и политических связей России с Европой. Первого им- ператора украшает отмена правежа, являвшегося «обыкновением азиатским». Кроме того, он называет Полтавскую битву одной из самых знаменитых в истории России, выигранной Петром I, который правил страной «в лучшие времена» [3, кн. 3, с. 206-207, 258, 268].

Разумеется, в те годы решительная борьба с Наполеоном осталась в прошлом, и нужды так накалять страсти больше не было. Н.М. Карамзин отмечал улучшение положения по меньшей мере в сфере русской литературы и образования. Россияне, по словам Н.М. Карамзина, не стремятся подражать иностранцам, но пишут и живут «как они», читая то, что и они. Однако Н.М. Карамзин отмечал, что Петр I, многое реформировав, не тронул всего настоящего русского. Будучи похожими на других европейцев, полагал Н.М. Карамзин, русские отличаются от них некоторыми талантами, привычками, умениями, поэтому, хотя и не всегда, можно «отличить россиянина от британца, но всегда отличим россиян от британцев: во множестве открывается народное» [2, т. 2, с. 238-239]. Упоминая факт передачи России нелестных картин Томмазо Долабеллы, посвященных Смуте, Н.М. Карамзин отметил, что во времена «еще славнейшие» могущественною рукою Петра I «стерты знамения слабости» [3, кн. 3 , c. 183-184].

Н.М. Карамзин одним из первых в русской общественной мысли поставил вопрос о негативных последствиях правления Петpa I, поскольку стремление этого императора преобразовать Россию в подобие Европы подрывали «дух народный», то есть верность народа самодержавию, православию, его моральные нормы и патриотизм. Стремление Петра I «к новым для нас обычаям переступило в нем границы благоразумия» [1, с. 195]. Н.М. Карамзин фактически обвинил императора в насильственном искоренении древних обычаев, роковом социокультурном расколе народа на высший, «онемеченный», слой и низший, «простонародье», в ликвидации патриаршества, что привело к ослаблению веры, в переносе столицы на окраину государства ценой огромных усилий и жертв. В итоге, утверждал Н.М. Карамзин, Петр I не смог найти «способ просветить ум 
россиян без вреда для их гражданских добродетелей» [1, с. 197].

Результаты. Итак, можно сказать, что взгляды Н.M. Карамзина на Петра I и его реформы не оставались неизменными. Будучи сначала либералом, страстным поклонником Петра I, он считал его героем, выведшим варварскую страну на путь цивилизации. «Письма русского путешественника» являются своеобразным апологетическим памятником Петру I, однако Н.М. Карамзин далек от раболепия перед царем.

Попытки реформ, совершаемые Александром I, вызвали усиление реакции. В значительной степени ее усилили внешнеполитические факторы, связанные с Наполеоновскими войнами. В этих условиях одним из самых ярких представителей консервативного крыла русской общественной мысли становится H.M. Карамзин, критиковавший Петра I как разрушителя национальных традиций. Осуждая царя-реформатора с консервативных позиций, он видел идеал в допетровской России. Вполне возможно, что в ряде вопросов определенное влияние на историка оказало мировоззрение Д. Дидро.

Однако после Отечественной войны 1812 г. в обстановке прилива патриотических настроений Н.М. Карамзин уже настаивает на поверхностном воздействии Петровских реформ. Подчеркивая их ограниченность, он отмечает уникальность русского народа, его национальную специфику. Во многом эти суждения формировались под воздействием консервативного отката последних лет правления Александра I. В конце жизни идейная эволюция взглядов Н.М. Карамзина на жизнь и реформы Петра I шла в сторону постепенного смягчения отношения к реформатору. Изменение отношения Н.М. Карамзина к Петру I в лучшую сторону стало свидетельством и одновременно проявлением именно такой эволюции. Улучшение отношения к Петру I, как представляется, означало отказ от прежних критических оценок. Однако это отнюдь не означало отход Н.M. Карамзина от консервативных позиций. Смерть историка в 1826 г. прервала его идейную эволюцию, тем не менее основная ее тенденция четко отметилась в предыдущие годы.

\section{СПИСОК ЛИТЕРАТУРЫ}

1. Карамзин, Н. М. Записка о древней и новой России в ее политическом и гражданском отношениях / Н. М. Карамзин // Ретроспективная и сравнительная политология. Публикации и исследования. - М. : Наука, 1991. - Вып. 1. - С. 185-254.

2. Карамзин, Н. М. Избранные сочинения : в 2 т. / Н. М. Карамзин. - М. ; Л. : Худож. лит., 1964. T. $1 .-810$ c. ; T. 2. $-591 \mathrm{c}$.

3. Карамзин, Н. М. История государства Российского : в 4 кн. : репринт/ Н. М. Карамзин. - М. : Книга, 1988-1989. - 4 кн.

4. Карамзин, Н. М. О любви к Отечеству и народной гордости / Н. М. Карамзин // Вестник Европы. -1802 . - № 4, ч. 1. - С. 56-69.

5. Кислягина, Л. Г. Формирование общественно-политических взглядов Карамзина (1785-1803) / Л. Г. Кислягина. - М. : Изд-во МГУ, 1976. - 201 с.

6. Китаев, В. А. Карамзин - консерватор / В. А. Китаев // Китаев, В. А. ХІХ век: пути русской мысли : науч. тр. - Н. Новгород : Изд-во Нижегор. гос. ун-та, 2008. - С. 7-28.

7. Лотман, Ю. М. Карамзин / Ю. М. Лотман. СПб. : Искусство-СПб, 1997. - 832 с.

8. Мезин, С. А. Дидро о Петербурге и Москве / С. А. Мезин // Столицы и провинция : материалы IV Междунар. конгр. петровских городов (г. Санкт-Петербург, 8-9 июня 2012 г.). - СПб. : Европ. дом, 2013. - С. 70-78.

9. Мезин, С. А. Дидро, Радищев и Карамзин / С. А. Мезин // «История в нас, мы в истории»: материалы Всерос. науч.-практ. конф. «Пугачевские чтения», посвященной 90-летию В.В. Пугачева (г. Саратов, 23-24 окт. 2013 г.). - Саратов : Изд-во ССЭИ РЭУ им. Г. В. Плеханова, 2014. C. $17-21$.

10. Минаков, А. Ю. Русский консерватизм в первой четверти XIX века / А. Ю. Минаков. - Воронеж : Изд-во Воронеж. гос. ун-та, 2011. -560 с.

11. Н.М. Карамзин : биобиблиогр. указатель / Ульян. гос. обл. науч. б-ка им. В.И. Ленина ; сост.: Н. И. Никитина, В. А. Сукайло. - Ульяновск : [б. и.], 1990. $-177 \mathrm{c}$.

12. Пирожкова, Т. Ф. Н.М. Карамзин - издатель «Московского журнала» (1791-1792) / Т. Ф. Пирожкова. - М. : Изд-во МГУ, 1978. -55 с.

13. Письма Н.М. Карамзина к И.И. Дмитриеву / сост.: Я. Грот, П. Пекарский. - СПб. : Изд. ІІ Отдния Императ. акад. наук, $1866 .-716$ c.

14. Русский консерватизм XIX столетия. Идеология и практика / В. Я. Гросул [и др.]. - М. : Прогресс-традиция, 2000. -440 с.

15. Советская историческая энциклопедия. В 16 т. Т. 11 / гл. ред. Е. М. Жуков. - М. : Сов. энцикл., 1968. - $521 \mathrm{c}$. 
16. Соловьев, Е. А. Петр Первый: метаморфозы образа (конец XVIII - начало XX века) / Е. А. Соловьев. - М. : Изд-во РУДН, 2009. - 288 с.

17. Шишков, А. С. Собрание сочинений и переводов. В 17 ч. Ч. 2 / А. С. Шишков. - СПб. : Тип. Императ. Рос. акад., 1824. - 471 с.

18. Шмурло, Е. Ф. Петр Великий в русской литературе : (Опыт историко-библиографического обзора) / Е. Ф. Шмурло // Журнал министерства народного просвещения. - 1889. - № 7. - С. 57-121 ; № 8. - C. 305-375.

19. Riasanovsky, N. V. The Image of Peter the Great in Russian History and Thought / N. V. Riasanovsky. Repr. ed. - Oxford : Oxford University Press, 1992. $352 \mathrm{p}$.

\section{REFERENCES}

1. Karamzin N.M. Zapiska o drevney i novoy Rossii v ee politicheskom i grazhdanskom otnosheniyakh [A Memoir on Ancient and Modern Russia]. Retrospektivnaya $i$ sravnitelnaya politologiya. Publikatsii $i$ issledovaniya [Retrospective and Comparative Political Science. Publications and Research]. Moscow, Nauka Publ., 1991, iss. 1, pp. 185-254.

2. Karamzin N.M. Izbrannye sochineniya: $v 2 t$. [Selected Works: in 2 vols.] Moscow; Leningrad, Khudozhestvennaya literatura Publ., 1964, vol. 1. 810 p.; vol. 2. $591 \mathrm{p}$.

3. Karamzin N.M. Istoriya gosudarstva Rossiyskogo: $v 4$ kn : reprint [History of the Russian State: in 4 Books. Reprint]. Moscow, Kniga Publ., 19881989.

4. Karamzin N.M. O lyubvi k Otechestvu i narodnoy gordosti [On Love for the Fatherland and on Native Pride]. Vestnik Evropy, 1802, no. 4, part 1, pp. 56-69.

5. Kislyagina L.G. Formirovanie obshchestvennopoliticheskikh vzglyadov Karamzina (1785-1803) [Formation of Social and Political Views of Karamzin (17851803)]. Moscow, Izd-vo MGU, 1976. 201 p.

6. Kitaev V.A. Karamzin - konservator [Karamzin as a Conservative]. Kitaev V.A. XIX vek: puti russkoy mysli: nauch. tr. [The $19^{\text {th }}$ Century: the Ways of Russian Thought: Scientific Works]. Nizhny Novgorod, Izd-vo Nizhegor. gos. un-ta, 2008, pp. 7-28.

7. Lotman Yu.M. Karamzin. Saint Petersburg, Iskusstvo-SPb Publ., 1997. 832 p.

8. Mezin S.A. Didro o Peterburge i Moskve [Diderot about Petersburg and Moscow]. Stolitsy $i$ provintsiya: materialy IV Mezhdunar. kongr. petrovskikh gorodov (g. Sankt-Peterburg, 8-9 iyunya 2012 g.) [Capitals and the Province. Proceedings of the $4^{\text {th }}$ International Congress of Peter's Cities (St. Petersburg, June 8-9, 2012)]. Saint Petersburg, 2013, pp. 70-78.

9. Mezin S.A. Didro, Radishchev i Karamzin [Diderot, Radishchev and Karamzin]. «Istoriya $v$ nas, my $v$ istorii»: materialy Vseros. nauch.-prakt. konf. "Pugachevskie chteniya», posvyashchennoy 90-letiyu V.V. Pugacheva (g. Saratov, 23-24 okt. 2013 g.) ["History in Us, We Are in History": Materials of the All-Russian Scientific and Practical Conference "Pugachev's Readings", Dedicated to the $90^{\text {th }}$ Anniversary of V.V. Pugachev (Saratov, October 2324, 2013)]. Saratov, Izd-vo SSEI REU im. G.V. Plekhanova, 2014, pp. 17-21.

10. Minakov A.Yu. Russkiy konservatizm v pervoy chetverti XIX veka [Russian Conservatism in the First Quarter of the $19^{\text {th }}$ Century]. Voronezh, Izd-vo Voronezh. gos. un-ta, 2011. $560 \mathrm{p}$.

11. Nikitina N.I., Sukaylo V.A., eds. N.M. Karamzin: biobibliogr. ukazatel [N.M. Karamzin: Bibliographic Index]. Ulyanovsk, 1990. $177 \mathrm{p}$.

12. Pirozhkova T.F. N.M. Karamzin - izdatel «Moskovskogo zhurnala» (1791-1792) [N. M. Karamzin is the Publisher of the Moscow Journal (1791-1792)]. Moscow, Izd-vo MGU, 1978. 55 p.

13. Pisma N.M. Karamzina k I.I. Dmitrievu [Letters by N.M. Karamzin to I.I. Dmitriev]. Saint Petersburg, Izd. II Otd-niya Imperat. akad. nauk nauk, $1866.716 \mathrm{p}$.

14. Grosul V.Ya., ed. Russkiy konservatizm XIX stoletiya. Ideologiya i praktika [Russian Conservatism of the $19^{\text {th }}$ Century. Ideology and Practice]. Moscow, Progress-traditsiya Publ., 2000.440 p.

15. Sovetskaya istoricheskaya entsiklopediya. V16 t. T. 11 [Soviet Historical Encyclopedia. In 16 vols. Vol. 11]. Moscow, Sov. entsikl. Publ., 1968. 521 p.

16. Solovyev E.A. Petr Pervyy: metamorfozy obraza (konets XVIII - nachalo XX veka) [Peter I: Metamorphoses of the Image (End of the $18^{\text {th }}$ Beginning of the $20^{\text {th }}$ Century)]. Moscow, Izd-vo RUDN, 2009. 288p.

17. Shishkov A.S. Sobranie sochineniy $i$ perevodov. $V 17 \mathrm{ch}$. Ch. 2 [Collection of Essays and Translations. In 17 parts. Part 2]. Saint Petersburg, Tip. Imp. ros. akad., 1824. $471 \mathrm{p}$.

18. Shmurlo E.F. Petr Velikiy v russkoy literature : (Opyt istoriko-bibliograficheskogo obzora) [Peter the Great in Russian Literature (Experience of Historical and Bibliographic Review)]. Zhurnal ministerstva narodnogo prosveshcheniya, 1889, no. 7, pp. 57-121; no. 8, pp. 305-375.

19. Riasanovsky N.V. The Image of Peter the Great in Russian History and Thought. Oxford, Oxford University Press, 1992. 352 p. 


\section{Information about the Author}

Ruslan R. Dzhabbarov, Postgraduate Student, Department of History, Philosophy, Political Science and Sociology, Saratov Socio-Economic Institute (Branch) of Plekhanov Russian University of Economics, Radishcheva St., 89, 410003 Saratov, Russian Federation, dzhabbarovruslan@yandex.ru, https://orcid.org/0000-0002-0382-2080

\section{Информация об авторе}

Руслан Рашидович Джаббаров, аспирант кафедры истории, философии, политологии и социологии, Саратовский социально-экономический институт (филиал) Российского экономического университета им. Г.В. Плеханова, ул. Радищева, 89, 410003 г. Саратов, Российская Федерация, dzhabbarovruslan@yandex.ru,https://orcid.org/0000-0002-0382-2080 